\title{
Ruhsal Zeka ve Çalışma Algısı Üzerine Bir Analiz*
}

\author{
Ümmühan Yİ̈̆IT SEYFI** Sevinç KÖSE***
}

$\ddot{O} Z$

Günümüz işletmeleri farklı kültürlerden ve kuşaklardan çalışanların bir arada faaliyet gösterdiği mozaik örgüt yapısına sahiptir. Bu yapıda işletmelerin çalışanlarlyla birlikte varlıklarını bir bütün olarak sürdürebilmeleri için ruhsal zeka yeteneklerinin geliştirilmesi gerekmektedir. Ruhsal zeka bütüncül yaklaşımı sağlayan birleştirici bir düşünme türüdür. Ruhsal zeka; kim olduğunun farkında olmak ve bu farkindalıkla hayatı yaşamaktır. Bu araştırma ruhsal zeka ile çalışma algısı arasındaki ilişkilerin niteliğini sorgulamak üzere tasarlanmıştır. Araştırma amacına yönelik öncelikle ilgili yazın incelenmiştir. Araştırma verilerinin toplanmasında Ruhsal Zeka ÖzRapor Envanteri (SISRI-24), İş Görme Anlayışı Ölçeği (IGA) kullanılmıştır. Anketlerden elde edilen veriler SPSS 22 istatistik paketi ile analiz edilmiştir. Demografik verilerden yararlanılarak örneklemin profili belirlendikten sonra, ölçeklerin geçerlik ve güvenirlik analizleri, faktör analizleri yapılmıştır. Araştırma hipotezlerini test etmek üzere korelasyon, regresyon, $t$ testi ve ANOVA analizleri yapılmıştır. Ruhsal zeka ile çalışma algısı arasında anlamlı bir iliş̧ki olduğu sonucuna ulaşılmıştır ve kurulan model kabul edilmiştir. Ruhsal zeka düzeyindeki artış çalışma algısını pozitif yönde etkilemektedir.

Anahtar Kelimeler: Zeka, Ruhsal Zeka, Çalışma Algısı, İ̧̧ Görme Anlayışı, İnsan Kaynakları Yönetimi

JEL Sinıflandirması:M12, M14, M54

\section{The Analysis on Spiritual Intelligence and Working Perception}

\begin{abstract}
In today's world, companies have mosaic organization structure in that employees with different cultures and generations work together. In this structure, to sustain existence of the companies with their employees as a whole, it is important to improve spiritual intelligence of employees. Spiritual intelligence is a kind of connective thinking that provides holistic approach. Spiritual intelligence is being aware of who you are and is living life with this awareness. This research is designed to understand the nature of the relationships between spiritual intelligence and working perception. First of all the related literature were examined aiming for research purpose. The survey instrument through which the research were conducted consists of 'The Spiritual Intelligence Self-Report Inventory (SISRI-24), Work Mentality(IGA) Questionnaire. The data were analyzed using Statistical Package for Social Sciences (SPSS) 22. After profiles were determined benefiting from demographic data of the sample, the reliability and validity of the instruments, factor analysis were performed. Correlation, regression, $t$-test and ANOVA techniques have been used to analyse the data. Results of the study indicate that there is a statistically significant positive relationship between spiritual intelligence and work perception and established model was adopted. The increase in spiritual intelligence level positively affects the work perception.
\end{abstract}

Key Words: Intelligence, Spiritual Intelligence, Working Perception, Work Mentality, Human Resources Management

JEL Classification: M12, M14, M54

\footnotetext{
* Bu çalışma, ilk yazarın "X ve Y Kuşaklarının Ruhsal Zeka Özellikleri ile Çalışma Algıları Üzerine Bir Analiz" isimli doktora tezinden türetilmiştir.

** Dr., yigitseyfi@gmail.com

*** Prof. Dr., Celal Bayar Üniversitesi, İiBF, İşletme Bölümü, sevinç.köse@cbu.edu.tr

(Makale Gönderim Tarihi: 08.04.2016 / Yayına Kabul Tarihi: 29.11.2016)
}

Doi Number: 10.18657/yonveek.281963 


\section{GíRiş}

Çalışanların örgüt açısından etkinlik ve verimliliğini artırma çabası her zaman güncelliğini korumuştur. Çalışma hayatındaki dönüşümler ve sürekli yenilenmeler, kişilerin çalışma disiplinlerini etkilemekte ve çalışan davranışlarının yeniden okunması ihtiyacını doğurmaktadır.

$\mathrm{Bu}$ araştırma, ruhsal zeka özellikleri ile çalışma algısı arasındaki ilişkilerin niteliğini ortaya koyarak, ruhsal zeka özellikleriyle çalışma algısının beklenilen yönde yönlendirilmesini sağlamak amacıyla planlanmıştır. Konuyla ilgili çeşitli yerli ve yabancı kaynaklar, kuramsal araştırma sonuçları değerlendirilmiştir. Yazın taraması, "ruhsal zeka bilinci gelişen çalışanlarda, çalışma algısı ve iş görme anlayışı pozitif yönde etkilenir" beklentisini ortaya çıkarmıştır. Bu pozitif eğilimle çalışanlar arasındaki çatışmaların da azalacağı umulmaktadır. Ruhsal zeka özelliklerinin geliştirilmesiyle iş görenlerin çalışma algıları istenilen yönde etkilenebilir. $\mathrm{Bu}$ yönüyle çalışmamız günümüz iş dünyasının çalışan sorunlarına farklı bir perspektiften çözüm önermesi açısından önemlidir.

Ruhsallığın temelinde, insan varlığının da özünü oluşturan, dört ana kavram bulunmaktadır: beden, akı1, kalp ve ruh. Moxley'e (2000) göre; bireylerin verimliliği için bu dört unsurun bir araya getirilmesi gerekmektedir. Bu unsurlar arasında işbirliği ve uyuşma olmazsa, insan yaptığı işten haz alamaz, kendini ifade edemez ve işlerinde yeterli olamaz. Levy'nin (2000) ifadesiyle; insanın tatmin edilmesi gereken hem fiziksel ve zihinsel hem de duygusal ve ruhsal ihtiyaçları vardır. İşine gittiği zaman hiç kimse bu ihtiyaçlarından sıyrılarak, bunlar1 kapı önünde bırakıp ofisine giremez (Baloğlu ve Karadağ, 2009, s. 173175).

Yönetimde sadece üretim artışına odaklanan bir anlayış rekabeti artırırken, yenilenme ruhunu azaltmaktadır. Uyumlu çalışmaya yönlendirirken, durgunluğa yol açmaktadır. Çalışanlarda bağl1lıktan ziyade itaat duygusu ön plana çıkmaktadır. Warren Bennis'in ifadesiyle bu anlayışa sahip örgütler; "insan ruhunun hapishaneleri" haline gelir (Bennis, 2001, s.13). Bu esaretten ancak kendilerine "niçin" sorusunu soran ve cevabını arayan yönetici ve çalışanların ruhu kurtulabilir (Özdemir ve Yiğit Seyfi, 2015, s. 231).

"Ruhsal zeka ile çalışma algısı arasında anlamlı bir ilişki olabilir mi?" sorusunu düşündüren faktörlerin başında; insanın işinde anlam, amaç, bütünlük ve sosyallik arayışı gelmektedir. Ayrıca çalışma algısının sadece fiziksel değil, ruhsal sebeplerle de alakalı olmasi; kaynağı her ne olursa olsun, alg1 sonucu oluşan sıkıntıları aşmada ağırlıklı olarak ruhsal çözümlerin kullanılması; ruhsal ve duygusal alandaki yeteneklerin yetersizliğinin veya eksikliğinin örgütün gelişmesinde ve büyümesinde engel olması; ruhsal zekanın örgüt yaşamında rolü ve önemi, ruhsal zeka ve kişilik arasında ilişkinin olduğunu gösteren araştırma bulguları; klasik yönetim anlayışının yerini, beden işçiliğinden ziyade insanda kalp, kafa ve ruh bütünlüğü gerektiren çalışma anlayışına bırakması; bilgi toplumunda iş değerlerindeki dönüşümün (yenilikçilik, esneklik, kendini gerçekleştirme ve farklılığını ortaya koyma, sorumluluk yüklenebilme, vizyon 
sahibi olma, diğer inançlara ve insan haklarına saygı, andan keyif alma, değişime ayak uydurabilme, şeffaflık gibi), ruhsal zeka yetenekleriyle örtüşüyor olması ruhsal zeka ile çalışma algısı arasında anlamlı bir ilişkinin olabileceği düşüncesini kuvvetlendirmiştir. $\mathrm{Bu}$ yönüyle çalışma algısının istenilen biçimde yönlendirilmesinde, ruhsal zekanın önemli bir rolü olduğu düşünülebilir.

Günümüzün çalışma anlayışında insanı fiziksel, zihinsel, duygusal ve ruhsal yönüyle bir bütün olarak ele alan yaklaşımlara ihtiyaç olduğu görülmektedir. Bu bağlamda bütüncül bir yaklaşım ve düşünme türü olarak ruhsal zeka ve özellikleri çalışan algısında ve davranışlarında, yeni fark edilen bir değişken olarak araştırmacının karşısında, cevaplanmayı bekleyen pek çok sorusuyla durmaktadır. Bu araştırmanın ana teması olan ruhsal zeka kavramı için öncelikle 'Ruhsal zeka bilimsel bir gerçek mi, yoksa özellikle iş dünyasının ilgisini cezbetmek için uydurulmuş bir efsane mi?' sorusunun tatmin edici seviyede cevabı aranmıştır. Gardner'a göre, bir yeteneğin zeka olarak nitelenebilmesi için; onunla ilgili beyinde duyarlı bir alanın bulunması ve bu alanın hasar görmesi halinde, bu yeteneğin de büyük ölçüde yitirilmesi gerekir (Gardner, 2012, s. 5-6). Bu bağlamda başta A. Damasio'nun (1994), (2000) ve bunu destekleyen klinik araştırmaları olmak üzere ruhsal yeteneklerin bir zeka olarak nitelenebilmesi için anatomik ve fizyolojik alt yapısıyla gerekli ölçütleri karşıladığı, geniş çaplı yapılan yazın araştırması sonucunda görülmüştür.

Uluslararası yazında kendine geniş yer bulan ruhsal zeka; ülkemizde yeni fark ettirilmeye çalışılan bir konu olarak, akademik yazında yeterince tartışılmamıştır. $\mathrm{Bu}$ araştırmanın, pozitif bilimin sağlam verilerine dayanarak, disiplinlerarası bir yaklaşımla ele alınması, pozitif bilimin ve metafiziğin işbirliğiyle rasyonel tabana oturtulmaya çalışılması yönüyle yazına yeni bir kaynak olarak katkıda bulunacağı umulmaktadır. Ancak ayrıntısına girmek bu makalenin sınırlarını kat kat aşacağından uygulama ağırlıklı biçimde yer verilmesinin daha önemli olacağı düşünülmüştür.

\section{YAZIN TARAMASI VE KURAMSAL ÇERÇEVE}

\section{A. Ruhsal Zeka}

Ruhsal zeka; insanların anlamlı kararlar verirken, var olan konular üzerinde düşünürken, günlük hayattaki problemleri çözerken ve aynı zamanda çalışma ve refah düzeyini arttırma yolunda kullandıkları ruhsal kaynakları, değerleri ve nitelikleriyle somutlaştırdıkları bir yetenekler kümesidir (Forghania vd., 2014, s. 292; Akgemci ve Bekiş, 2013, s. 288). Bir başka ifadeyle ruhsal zeka; potansiyel olarak var olan ruhsal yeteneklerin ve kaynakların pratikte uygulanması olarak tanımlanmaktadır.

Ruhsal zeka kavramını ilk olarak ortaya çıkaran araştırmacılar Zohar ve Marshall olmuştur. Ruhsal zeka insanın; yeniyi üretebilme, kuralları gerektiğinde değiştirebilme, ahlak duygusunun aktifleştirilmesi, katı kuralları anlayışla ve merhametle esnetebilme, anlayış ve merhametin sınırlarını tespit edebilme, olayları farklı perspektiften değerlendirebilme kabiliyetini geliştirmektedir (Zohar ve Marshall, 2004, s. 18). 
Ruhsal zeka; bilişsel zeka(IQ) ve duygusal zeka(EQ)'nın ruhsal korelasyonunu belirtmek için kullanılan bir terimdir. EQ gibi, ruhsal katsayı (SQ) kullanımı bilimsel araştırma ve tartışma alanında daha yaygın hale gelmektedir. Stephen Covey'e göre SQ, merkez ve tüm zekaların en temelidir çünkü diğerleri için rehberlik kaynağı olmaktadır (Covey, 2004'den aktaran Chaudhary ve Aswal, 2013, s. 1509). Zohar'a göre, zeka çeşitlerinin sayıs1 ne kadar artarsa artsın temelde bu zeka çeşitleri, beyindeki üç temel sinir sistemimizden biriyle bağlantılıdır yani IQ, EQ ve SQ'nun varyasyonlarıdır. İdeal olanı; IQ, EQ ve SQ'nun birlikte ve birbirlerini destekleyerek çalışmalarıdır. Beyinlerimiz bunu yapabilecek şekilde tasarlanmıştır (Zohar ve Marshall, 2004, s. 16-17). Bir ifadeyi, akıl zekamızla algılar ve duygusal zekamızla içselleştiririz. Kavramak, yani derin anlamı yakalamak üçüncü boyut olan ruhsal zekamızın işlevidir (Uslu Üstten, 2008, s. 17,37).

Gardner'ın, bilimsel kriterlerle niceliksel olarak ölçülme zorluğundan dolayı çoklu zeka kuramında yer vermemesine rağmen, Emmons, (2000); Wolman, (2001); Vaughan, (2002); Nasel, (2004); Zohar ve Marshall (2004); Amram, (2007) gibi teorisyenler ve araştırmacıların bir çoğu ruhsal zekanın özerk bir insan zekası veya beceri kümesi olarak tanınması için gayret etmişlerdir (aktaran King, 2008, s. 38).

"Ruhsal zekanın temeli, anlam bulma özleminde ve ihtiyacında yatar" (Aydıntan, 2009, s. 260). Ruhsal zeka eksikliğinde; depresyon, şiddet dolu bir yaşam, uyuşturucu bağımlılığı, aile hayatı ve arkadaş ilişkilerinde ve hayatta başarısızlık gibi sorunlarla karşılaşıldığ 1 somut bir bilgi olarak bulunmaktadır. Batı, terk ettiği değerleri modern yaşamın kazanımlarını koruyarak "psikoloji" kimliğiyle tekrar hayata geçirmeye başlamıştır. Bunun ifade şekillerinden biri de duygusal zeka ve bir üst boyutunu keşfedenler için ise hem bilişsel hem de duygusal zekayı kapsayan ruhsal zeka kavramı olmuştur. "Kızgın, asi, sinirli, kaygıll, dürtüsel, saldırgan tavırların azalıp; nazik, şefkatli tutumların artması akıl ve kalbin birleştirilerek eğitilmesini gerektirir" (Tarhan, 2013, s. 21-22). Bu işbirliği ise ruhsal zekanın bir fonksiyonudur.

Ruhsal zekanın beyindeki sinirsel temellerini aşikar hale getiren temel araştırmaların çoğu, bilim adamları tarafından yapılmıştır. Örneğin; M.Persinger, V.S.Ramachandran'nın araştırmaları; W.Singer'in "bağlayıcı sorunu" çalışması; R.Llinas'ın "40 Hz'lik salınımlar” çalışması; Terrance Deacon'un dilin kökenine ilişkin çalışması (aktaran Zohar ve Marshall, 2004, s. 25-27).

Son çalışmalar $40 \mathrm{~Hz}$ 'lik frekans aralığında yoğunlaşmaktadır (Singer, 1999, s. 391). Nöronlar arasındaki ilişki yönlerini belirlemek mümkün olmasa da, birbirlerinden uzak beyin yapıları arasındaki işbirliğini anlamada bu salınımlar önemli bir bilgidir (Başar, 2013, s. 291). Beyinde bilinçli aktivite sırasında sıklıkla kaydedilen beyin çapındaki bu salınımlar deneyimlerimizin bir arada tutulması ve geniş bir anlam çerçevesine yerleştirilmesi konusunu aydınlatmaktadır. Zohar'a göre; $40 \mathrm{~Hz}$ 'lik salınımlar ruhsal zekamızın sinirsel alt yapısıdır (Zohar ve Marshall, 2004, s. 104). 
Zeka kavramını Zohar'ın ele aldığı şekilde değerlendirdiğimizde, bilişsel zeka; rasyonel, mantıklı düşünmeyi, problem çözmeyi sağlayan zeka türüdür ve "neokorteks" tarafindan yönetilir. Duygusal zeka; duyguların tanınmasını, ifade edilmesini ve bireyin kendisini karşıdakinin yerine koyarak düşünmesini sağlayan zeka türü olarak "amigdala" tarafından yönetilir. Ruhsal zeka ise neye inanacağımızı, ne soracağımızı, neyi değiştireceğimizi ve ne geliştireceğimizi belirler ve "frontal lob (ön lob)" tarafından yönetilir (Uslu Üstten, 2008, s. 92).

Diğer beyin alanlarıyla karmaşık ilişkiler içinde bulunan frontal lob; alnın etrafında bulunan, bilinçli kararların alındığı, yeni şeyler geliştirme, problem çözme, karar verme ve planlama gibi maksatlı faaliyetleri kapsayan ve ahlak, duygu, akıl, hırs gibi insan davranışlarının yer aldığ 1 hayatta kalma mekanizmamızı işleten bir alandır. Bu alan limbik sistemden gelen uyaranları işlemekte ve sosyal davranışlarımızı kontrol etmektedir (E. Keleş ve Çepni, 2006, s. 73; Jensen, 1998, s.9). Frontal lobun işleviyle insan, hem analitik hem duygusal düşünerek olaylara çeşitli açılardan bakar ve sonuçta iradesini kullanır (Tarhan, 2013, s. 33). Amigdalanın ani ve hatta fevri tepkilerine karşı tampon vazifesi görerek daha akılcı ve uygun bir tepki verilebilmesine olanak tanır. Böylelikle ruhsal zeka hissettiklerimize düşüncelerimizi katarak şuurlu davranışlar sergilememizi sağlamaktadır.

İç dünyamızı zenginleştirmede aktif rol oynayan ruhsal zeka, Zohar tarafindan 12 özellik ile ifade edilmektedir: öz farkındalık, kendiliğindenlik, vizyon ve değeri yönlendirme, bütüncüllük, şefkat, farklılıkları kutlamak, alan bağımsızlığı, temel sorular sorma veya kökten sorgulama eğilimi, yeniden çerçeveleme yeteneği, zorlukların yapıcı kullanımı, alçakgönüllülük ve meslek anlayışı (Zohar, 2004).

Uluslararası yazında yaygınlaşan ruhsallık, ruhsal kurumlar, iş yeri ruhsallığı ve ruhsal liderlik gibi kavramlar ruhsal zekayla ilgili olup bunlarla ruhsal zekanın farklı yönleri ifade edilmektedir. Kurumların kişisel ve örgütsel açıdan ihtiyaç duyduğu "derinden bağlılık ve anlam arayışı" ruhsal zeka yeteneklerinin aktifleştirilmesiyle karşılanabilecektir (Özdemir ve Yiğit Seyfi, 2015, s. 232).

Ruhsal zekanın tanımladığı; bireyin kendini bilmesi, kontrol etmesi ve motive etmesi, anı değerlendirebilmesi, vizyon sahibi olabilmesi, bütüncül bir düşünce yeteneği geliştirebilmesi, problemlere farklı açılardan bakabilmesi, koşulsuz diğerlerini sevebilmesi, şefkatli olması, derin empatiyi hissedebilmesi, etkin ilişkiler kurup sürdürebilmesi, farklılıkları soruna değil fursata dönüştürebilmesi, diğer kişilere anlayışla yaklaşabilmesi, kendi inançlarını yaşayabilmesi, gerektiğinde kalabalığa karşı durabilmesi, yaşamın anlamını aramas1, temel sorular sorma veya kökten sorgulama eğilimi, durum veya sorunları yeniden biçimlendirebilmesi, zorluklar karşısında direnebilmesi, alçak gönüllü olabilmesi ve insanlığa hizmet etme bilinci, özetle kendi kendini yönetebilmesi özellikleri öğrenilebilir becerilerdir. İnsanoğlu bu becerileri geliştirerek yaşamdaki başarısını ve doyumunu üst düzeylere çıkarabilir. 


\section{B. Çalışma Kavramı ve İş Görme Anlayışı}

Çalışma kavramını Tınar (1996) ve Bozkurt (2000)'un tanımlarından yararlanarak: "Bedensel, zihinsel ve ruhsal enerji harcayarak maddi ve manevi bir kazanç karşı1lı̆ı kendisi veya başkaları için değerli mal ve hizmetler ürettiği amaçlı ve sürekli sosyal bir faaliyet" olarak tanımlayabiliriz.

İş görme anlayışı (İGA); "bireylerin, grupların veya kurumların belli bir amaca ulaşmak üzere gerçekleştirdikleri etkinlikler sırasında, sahip oldukları değer ve bilgilerin etkisiyle geliştirdikleri bir tutum" (Aldemir vd., 2003) olarak tanımlanmaktadır.

Bilgi toplumuna geçişle birlikte çalışma hayatına ilişkin değerlerde dönüşümler yaşanması iş görme anlayışını da etkilemiş̧ir. Sanayi toplumundaki imalat ağırlıklı işlerden bilgi ve hizmet işlerine doğru olan yöneliş, nitelikli işgücüne ihtiyacı da birlikte getirmiştir. Aşırı uzmanlaşma ile insanın bedensel olarak dahi bütününe ihtiyaç duymayan klasik yönetim anlayışı yerini; beden işçiliğinden ziyade insanda kalp, kafa ve ruh bütünlüğü gerektiren çalışma anlayışına bırakmıştır.

Günümüz örgütleri; değerleri, inançları ve tutumlarındaki farklılıktan dolayı işe yaklaşımları, tatmin ve motivasyon araçları birbirinden apayrı grupların ve kuşakların faaliyet gösterdiği çalışma alanı haline gelmiştir. Bu mozaik örgüt yapısında çatışmaları azaltmak ve verimliliği sağlamak için çalışanlara karşı sergilenecek doğru tavırları, kullanılacak doğru enstrümanları bulmak; her bir gruba göre farklı davranırken diğer taraftan bunlar arasındaki dengeleri sağlamak çoğu yönetici için güç bir süreç olarak görülmektedir (Köse vd., 2014, s. 152). Ancak ruhsal zeka özelliklerinin kazanımıyla çalışma algısındaki farklılıklar avantajlı hale dönüştürülebilir.

\section{Ruhsal Zekanın Örgüt Yașamında Rolü ve Önemi}

Ruhsal değerlere sahip bireylerin bulunduğu örgütler, takım çalışmasına yatkındırlar. Bireysel olarak da dinleyen, öğrenen, deneyen, gelişen ve geliştiren üretici bir kişilik yapısına sahiptirler (Baloğlu ve Karadağ, 2009, s. 173). Ayrıca ruhsal zeka, hem üstlerin hem de astların birbirlerine derin anlayışlar beslemelerini ve akabinde buna uygun davranışlar sergilemelerini kolaylaştırmaktadır.

Örgütlerde esneklik düzeyi yüksek insanlar yeni fikirlere açıktırlar ve değişimlere direnç göstermezler. Esnek olma kapasitesi ise yüksek seviyede gelişmiş ruhsal zekanın göstergelerindendir (Zohar ve Marshall, 2004, s. 30).

Ruhsal zekaya sahip liderler, hem kendi faaliyetlerine yön veren açık ve net kişisel değerlere ve inançlara sahiptirler hem de çalışanların hedeflerine ulaşmalarına yardımcı olacak davranışlarını etkileyecek örgütsel vizyon ve değerleri belirleyebilme kaynaklarına sahiptirler. Böylelikle belirledikleri amaç ve değerler doğrultusunda örgütte istedikleri dönüşümü gerçekleştirebileceklerdir (Aydıntan, 2009, s. 259). Özleriyle kurdukları bağ sayesinde alçak gönüllülüğü elden bırakmayarak kendilerini bir kenara koyup, çalışanlara, kuruma ve müşterilere daha iyi hizmet verebilmektedirler (Baloğlu ve Karadağ, 2009, s. 176). Bu kişiler belirsiz, zor ya da sıkıntılı durumları çabuk aşabilmekte, hatta 
sonrasında eski performanslarının üstünde başarı gösterebilmektedirler. Ayrıca yaşamlarını sorgulayarak köklü değişimlere kolay uyum sağlayabilmektedirler (Kesken ve Ayyıldız, 2008, s. 739).

Zohar; tüm düşünme modellerinin değişiyor olduğu çağımızda, bilişsel ve duygusal zekamızın yüksek olsa dahi bizlere yetmeyeceğini ve ruhsal zekamızla bağlantı kurmamız gerektiğini ifade etmektedir (Zohar ve Marshall, 2004, s. 402). Çünkü ruhsal zeka düşüncelerimiz ile duygularımızın makul bir şekilde davranışa dönüştürülmesinde önemli düzeyde role sahiptir.

$\mathrm{Bu}$ araştırmanın kuramsal arka planına dayanarak diyebiliriz ki: İnsan kaynakları yöneticilerine göre, bireylerin işe girmeleri bilişsel zeka düzeyleriyle (IQ), terfileri duygusal zeka düzeyleriyle (EQ) gerçekleşirken kurum için vaz geçilmez eleman olmaları ise ruhsal zeka düzeyleriyle (SQ) gerçekleşmektedir.

\section{ARAŞTIRMA DEĞERLENDİRILMESI}

\section{A. Araştırmanın Yöntemi}

$\mathrm{Bu}$ araştırmanın temel sorusu: ruhsal zeka ile çalışma algısı arasında bir ilişki olup olmadığıdır. Araştırma sorusuna bağlı olarak, geliştirilen ana hipotez: "Ruhsal zeka ile çalışma algısı arasında anlamlı düzeyde ilişki bulunmaktadır." Bağımlı değişken çalışma algısında; bağımsız değişken olarak kişinin ruhsal zeka düzeyi ele alınmıştır. Böylece çalışma yaşamı ve örgütü ele alan çalışmalarda şimdiye kadar incelenmeyen bir konu olduğu için yazındaki önemli bir eksikliğin giderileceği düşünülmüsşür.

Araştırmanın evreni; Celal Bayar Üniversitesi'nde görevli olan akademisyenlerdir. Gönüllü örnekleme tekniği kullanılarak dönen anket sayısı araştırma örneklemi olarak alınmıştır. Bu çapta bir çalışma için yazında araştırma örnekleminin asgari 138 veri olması gerekmektedir. Çalışma 219 geçerli veri ile sürdürülmüştür.

Araştırmanın kısıtları; maliyete ve zamana ilişkin kısıtlar nedeniyle Türkiye'deki farklı üniversitelerde görev yapan akademisyenlere yönelik bir araştırma yapılamamıştır. Araştırmada devlet-vakıf üniversitesi akademisyenleri arasındaki farklılıklar gözetilmemiştir.

Bireylerin ruhsal zeka özelliklerini belirlemek için 'The Spiritual Intelligence Self-Report Inventory (SISRI-24) - Ruhsal Zeka Öz-Rapor Envanteri' ölçüm aracı olarak kullanılmıştır. 2008'de David B. King tarafından geliştirilen ölçek 24 ifadeden oluşmaktadır. Ölçek 5'li likert olarak, 'benim için hiç doğru değil' ve 'benim için tamamen doğru' aralığında düzenlenmiştir. Çalışma algısını belirlemek için 'İş Görme Anlayışı (İGA)' ölçeği kullanılmıştır. Aldemir, Arbak ve Timurcanday Özmen (2003) tarafindan ülkemiz kültürel özellikleri dikkate alınarak geliştirilmiş olan İGA ölçeği, 58 ifadeden oluşmaktadır. Ölçek 5'li likert olarak, 'hiç temsil etmemektedir' ve 'tam anlamıyla temsil etmektedir' aralığında düzenlenmiştir.

Üç kısımdan oluşan anket formunda katılımcıların demografik özelliklerini tanımlamaya yönelik sorular, ruhsal zeka düzeylerini ölçen SISRI-24 ölçeği ve çalışma algısını ölçen İGA ölçeği bulunmaktadır. Araştırmanın amacını 
gerçekleştirmeye yönelik veriler e-posta yoluyla anket uygulaması yapılarak toplanmıştır.

\section{B. Verilerin İstatistiksel Analizi}

Araştırma verilerinin analizlerinde IBM Statistical Package Social Studies (SPSS) 22 programı kullanılmıştır. Öncelikle demografik özelliklerle ilgili bulgular, ortalama ve standart sapma gibi tanımlayıcı istatistikler incelenmiştir.

Verilerin faktör analizine uygunluğu açısından örneklemin yeterlilik tespiti için Kaiser-Meyer-Olkin (KMO) testi ve modelin geçerlilik tespiti için Bartlett Küresellik testi yapılmıştır. Temel Bileşenler Faktör Analiziyle (Principal Component Analysis-PCA) ölçeklerin boyutları belirlenmiş ve faktör ağırlığ olarak 0,40 ve üzeri temel alınmıştır.

Araştırmanın amacı, ruhsal zeka ile çalışma algısı arasındaki ilişkinin niteliğini belirlemek olduğu için korelasyon analizi yapılmıştır. Korelasyon katsayısı $r$ değeri için farklı yazarlar farklı önerilerde bulunmakla birlikte Cohen'e göre; $0,1<\mathrm{r}<0,29$ ise zayıf ilişki düzeyinden; $0,30<\mathrm{r}<0,49$ ise orta ilişki düzeyinden; $0,50<\mathrm{r}<1,0$ ise yüksek ilişki düzeyinden bahsedilebilmektedir (Cohen, 1988'den aktaran Pallant, 2010, s. 134). Sonuçlar \% 95 güven aralığında, anlamlılık $\mathrm{p}<0,05$ düzeyinde çift yönlü olarak değerlendirilmiştir.

\section{Katılımcıların Demografik Özelliklerinin Tanımlanması}

Araştırmaya katılan 219 akademisyenin demografik yapısıyla ilgili özellikler incelendiğinde, katılımcıların (\%65)'i 1960-1979 ve (\%35)'i 19802000 tarihleri arasında doğmuştur. Katılımcıların \% 53’ũ erkek, \%47'si kadındır. Katılımcılar ağırlıklı olarak (\%71) doktora ve üstü düzeyinde öğrenime sahiptir. Katılımcıların eğitim alanı açısından dağılımı; sosyal bilimler (\%47), fen bilimleri (\%33) ve sağlık bilimleri (\%19) şeklindedir. Katılımcıların \%26'sının deneyimi 1-6 yıl arasında, \%15'inin deneyimi 7-12 y1l arasında, \%23'ünün deneyimi 13-18 y1l arasında, \%19'unun deneyimi 19-24 y1l arasında, \%17'sinin deneyimi 25 yıl ve üzeridir. Katılımcıların ağırlıklı olarak \%77'si evlidir ve yetişme dönemindeki aile büyüklüğü ağırlıklı olarak (\%39) 4 kişiliktir.

\section{Ruhsal Zeka Ölçeğiyle İlgili Analizler}

$\mathrm{Bu}$ araştırmada SISRI-24 ruhsal zeka ölçeği için Cronbach's Alpha (\% 92) bulunduğundan yüksek bir güvenilirliğe sahiptir. Bartlett Küresellik testi ve KMO testi değerleri faktör analizi için verilerin uygun olduğunu ifade etmektedir $(\mathrm{p}<0,05 ; \mathrm{KMO}>0.50$ ) (Field, 2013, s. 685). 24 ifadeli ruhsal zeka ölçeğine faktör analizi uygulanmıştır. Analiz sonucu ulaşılan dört faktörlü yap1 toplam 22 ifadeden oluşmuş, 2 ifade yeterli yük almadığ 1 için kapsam dışında kalmıştır (Tablo 1). 
Tablo 1: SISRI-24 Ölçeği Faktör Analizi

\begin{tabular}{|c|c|c|c|c|c|c|}
\hline 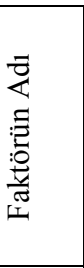 & Faktörü Oluşturan İfadeler & 掊 & 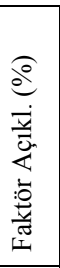 & 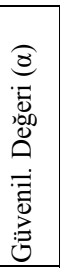 & 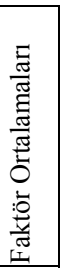 & 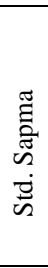 \\
\hline \multirow{10}{*}{ 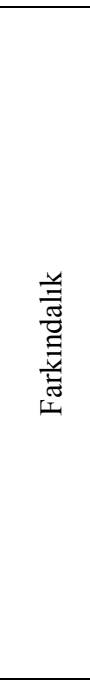 } & $\begin{array}{l}\text { Hayatın maddesel olmayan yönlerini tanımak ruhsal } \\
\text { ilerlememde bana yardımcı oluyor. }\end{array}$ & ,832 & \multirow{10}{*}{$\begin{array}{l}8 \\
\delta \\
n \\
\hat{n}\end{array}$} & \multirow{10}{*}{ ஓ. } & \multirow{10}{*}{$\begin{array}{l}8 \\
8 \\
0 \\
\text { r }\end{array}$} & \multirow{10}{*}{\begin{tabular}{l}
$\infty$ \\
\hdashline \\
0
\end{tabular}} \\
\hline & Hayatın maddesel olmayan yönlerinin farkındayım. & ,727 & & & & \\
\hline & $\begin{array}{l}\text { İnsan hayatında beden, kişilik ve duygulardan daha } \\
\text { anlamlı olan niteliklerin olduğunu düşünüyorum. }\end{array}$ & ,653 & & & & \\
\hline & $\begin{array}{l}\text { Kendimi daha iç, derinlemesine, fiziksel olmayan şekilde } \\
\text { tanımlayabiliyorum. }\end{array}$ & ,629 & & & & \\
\hline & $\begin{array}{l}\text { Herhangi bir hata yaptı̆̆ımda, yine de onun altında bir } \\
\text { anlam bulabiliyorum. }\end{array}$ &, 570 & & & & \\
\hline & Hayatımdaki olayların anlamını sık sık düşünürüm. & ,564 & & & & \\
\hline & $\begin{array}{l}\text { Maddesel ve ruhsal dünyam arasında rahatça } \\
\text { dolaşabiliyorum. }\end{array}$ &, 558 & & & & \\
\hline & $\begin{array}{l}\text { Kendim ve diğer insanlar arasındaki derin bağın } \\
\text { farkındayım. }\end{array}$ &, 551 & & & & \\
\hline & $\begin{array}{l}\text { Yaşamın anlamını ve amacını bulmam bana stresli } \\
\text { durumlarla baş etmemde yardımcı oluyor. }\end{array}$ &, 534 & & & & \\
\hline & $\begin{array}{l}\text { İnsanoğlu ve diğer tüm evren arasındaki ilişki hakkında } \\
\text { düşünebiliyorum. }\end{array}$ &, 503 & & & & \\
\hline \multirow{5}{*}{ 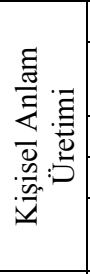 } & Hayattaki amacım doğrultusunda kararlar verebiliyorum. & 804 & \multirow{5}{*}{ 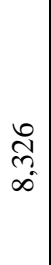 } & \multirow{5}{*}{$\bar{\infty}_{0}$} & \multirow{5}{*}{$\begin{array}{l}\hat{\hat{s}} \\
\infty \\
\dot{\infty}\end{array}$} & \multirow{5}{*}{ ত্రి } \\
\hline & $\begin{array}{l}\text { Düşüncelerimi, hislerimi ve farkındalıklarımı kontrol } \\
\text { edebiliyorum. }\end{array}$ & ,667 & & & & \\
\hline & Gündelik hayatımda amaç ve anlam bulabiliyorum. & ,644 & & & & \\
\hline & Hayatımın amacını ya da sebebini tanımlayabiliyorum. & 611 & & & & \\
\hline & Hayata anlam vermek ve yaşamın farkında olmak & 602 & & & & \\
\hline \multirow{4}{*}{ 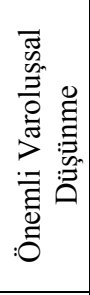 } & $\begin{array}{l}\text { Varoluşun temelini sık sık sorgularım ya da bunun } \\
\text { üzerinde çok fazla düşünürüm. }\end{array}$ & ,836 & \multirow{4}{*}{$\begin{array}{l}\infty \\
2 \\
r \\
r\end{array}$} & \multirow{4}{*}{ 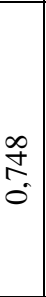 } & \multirow{4}{*}{ 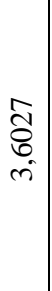 } & \multirow{4}{*}{$\stackrel{-1}{\infty}$} \\
\hline & $\begin{array}{l}\text { Varoluş nedenimi ya da amacımı düşünmek için zaman } \\
\text { harcarım. }\end{array}$ &, 824 & & & & \\
\hline & $\begin{array}{l}\text { Ölümden sonra ne olacağı konusunda düşünüp, } \\
\text { tartışabiliyorum. }\end{array}$ &, 554 & & & & \\
\hline & $\begin{array}{l}\text { Kendi iç dünyamın görünenden yani fiziksel bedenden } \\
\text { daha derin olduğunun farkındayım. }\end{array}$ & ,473 & & & & \\
\hline$\underline{\equiv} \cdot \vec{s}$ & $\begin{array}{l}\text { Yaşam, ölüm, gerçeklik ve varoluş gibi konularda kendi } \\
\text { teorilerimi geliştirdim.. }\end{array}$ & ,747 & & & & \\
\hline 竞竞 & $\begin{array}{l}\text { Bilinç ve farkındalığımı arttırmak için kendi tekniklerimi } \\
\text { geliştirdim. }\end{array}$ & 682 & $\stackrel{\varrho}{\equiv}$ & $\frac{ \pm}{\sigma}$ & 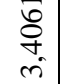 & $\stackrel{2}{0}$ \\
\hline$\stackrel{\Xi}{\Xi}$ & $\begin{array}{l}\text { Farkındalığım arttığında sorunları ve seçenekleri daha iyi } \\
\text { görebiliyorum. }\end{array}$ & , 435 & in & & & \\
\hline Toplan & Açıklanan Varyans: $\% 58,110$ & Olkin $\mathrm{C}$ & ç̧ek & jeçer & liği: & \\
\hline Bartlet & Küresellik Testi Ki kare: 2229,278 & \begin{tabular}{l|l}
231 & \\
\end{tabular} & & & & \\
\hline
\end{tabular}




\section{E. İş Görme Anlayışı Ölçeğiyle İlgili Analizler}

$\mathrm{Bu}$ araştırmada İGA ölçeği için Cronbach's Alpha (\% 81) olduğundan yüksek bir güvenilirliğe sahiptir. Bartlett Küresellik testi ve KMO testi değerleri faktör analizi için verilerin uygun olduğunu ifade etmektedir $(\mathrm{p}<0,05 ; \mathrm{KMO}>0.50)$ (Field, 2013, s. 685). 58 ifadeli İGA ölçeğine faktör analizi uygulanmıştır. Analiz sonucu ulaşılan sekiz faktörlü yapı toplam 39 ifadeden oluşmuş, 19 ifade yeterli yük almadığı için kapsam dışında kalmıştır (Tablo 2). Statü Odaklı İGA boyutunun güvenilirlik değeri 0,40'ın altında olduğu için hipotez testlerinde değerlendirilmeye alınmamıştır.

Tablo 2: İGA Ölçeği Faktör Analizi

\begin{tabular}{|c|c|c|c|c|c|c|}
\hline 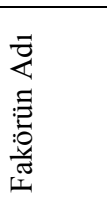 & Faktörü Oluşturan Değerler & 葶 & 掊 & 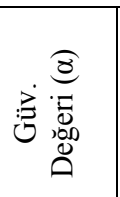 & 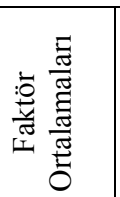 & 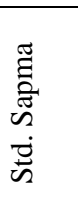 \\
\hline \multirow{6}{*}{ 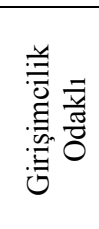 } & Girişkenlik & ,690 & \multirow{6}{*}{$\begin{array}{l}\infty \\
\stackrel{\infty}{\stackrel{5}{*}}\end{array}$} & \multirow{6}{*}{$\frac{\substack{+0}}{0}$} & \multirow{6}{*}{$\begin{array}{l}\stackrel{m}{\sigma} \\
\vec{\sigma}\end{array}$} & \multirow{6}{*}{$\begin{array}{l}n \\
\tilde{0}\end{array}$} \\
\hline & Çalışkanlık & 671 & & & & \\
\hline & İ́radelilik & 612 & & & & \\
\hline & İleri Görüşlülük & ,598 & & & & \\
\hline & Disiplin &, 587 & & & & \\
\hline & Girişimcilik & ,531 & & & & \\
\hline \multirow{6}{*}{ 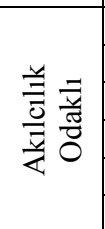 } & Bireyin Hak ve Özg.Önem Verm. & ,710 & \multirow{6}{*}{\begin{tabular}{l}
$\stackrel{n}{o}$ \\
\multirow{+}{*}{} \\
$=$
\end{tabular}} & \multirow{6}{*}{$\frac{\infty}{\stackrel{0}{\circ}}$} & \multirow{6}{*}{$\begin{array}{l}\stackrel{+}{\mathbb{N}} \\
\stackrel{\sim}{+}\end{array}$} & \multirow{6}{*}{$\begin{array}{l}o \\
0 \\
0\end{array}$} \\
\hline & Yetkinliğe Önem Vermek & 626 & & & & \\
\hline & Bilimsellik & ,606 & & & & \\
\hline & Kurallara Uymak &, 499 & & & & \\
\hline & Tevazu &, 496 & & & & \\
\hline & Ayrıntılara Önem Vermek & 462 & & & & \\
\hline \multirow{6}{*}{ 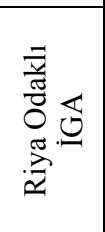 } & Gösteriş & ,640 & \multirow{6}{*}{ 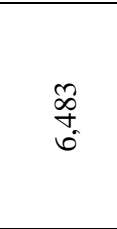 } & \multirow{6}{*}{$\begin{array}{l}0 \\
\text { రి } \\
0\end{array}$} & \multirow{6}{*}{$\frac{\hat{d}}{a}$} & \multirow{6}{*}{$\begin{array}{l}t \\
0 \\
0\end{array}$} \\
\hline & Hizipçilik &, 582 & & & & \\
\hline & Himayecilik &, 582 & & & & \\
\hline & Bağımlılık & ,537 & & & & \\
\hline & Duygusallık &, 522 & & & & \\
\hline & İkiyüzlülük &, 508 & & & & \\
\hline \multirow{6}{*}{ 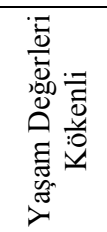 } & Kanaatkarlık & 650 & \multirow{6}{*}{$\begin{array}{c}\stackrel{\sigma}{\sigma} \\
\dot{\sigma}\end{array}$} & \multirow{6}{*}{$\begin{array}{l}8 \\
: \\
0 \\
0\end{array}$} & \multirow{6}{*}{$\underset{\text { S }}{\text { f }}$} & \multirow{6}{*}{$\begin{array}{l}\hat{b} \\
0 \\
0\end{array}$} \\
\hline & Kadercilik & 609 & & & & \\
\hline & Gelenekçilik & ,516 & & & & \\
\hline & Dostluk & 462 & & & & \\
\hline & Milliyetçilik & 449 & & & & \\
\hline & Din & 447 & & & & \\
\hline \multirow{3}{*}{ 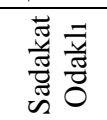 } & Vefa & ,768 & \multirow{3}{*}{ 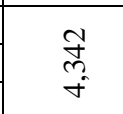 } & \multirow{3}{*}{$\begin{array}{l}5 \\
0 \\
0\end{array}$} & \multirow{3}{*}{$\tilde{r}_{0} 0$} & \multirow{3}{*}{$\hat{\circ}$} \\
\hline & Sadakat & ,734 & & & & \\
\hline & İtaatkarlık &, 469 & & & & \\
\hline \multirow{4}{*}{ 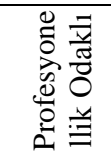 } & Sorguculuk & ,756 & \multirow{4}{*}{$\frac{⿱}{i}$} & \multirow{4}{*}{$\begin{array}{l}8 \\
\stackrel{0}{0} \\
0 \\
0\end{array}$} & \multirow{4}{*}{$\begin{array}{l}\hat{2} \\
\text { ळे }\end{array}$} & \\
\hline & Sorumluluk &, 562 & & & & $n$ \\
\hline & İş Birliği &, 507 & & & & 0 \\
\hline & Bilgi Paylaşımı & 426 & & & & \\
\hline 言 & Kuşkuculuk & 684 & & & & \\
\hline$\overline{0} \cdot 0$ & Kat1lık & 640 & mio & $08 \mathrm{in}$ & cas & 0 in \\
\hline
\end{tabular}




\begin{tabular}{|c|c|c|c|c|c|c|}
\hline & Maddiyatçı1ık & ,518 & \multirow{6}{*}{$\begin{array}{l}\text { ô } \\
\text { ஸे } \\
\text { m. }\end{array}$} & \multirow{6}{*}{$\frac{1}{3}$} & \multirow{6}{*}{ 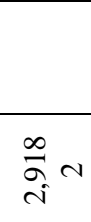 } & \\
\hline & Ç1karcılık & 439 & & & & \\
\hline & Rütbe ve Makama Önem Verm. &, 436 & & & & \\
\hline \multirow{3}{*}{ 壱 } & Uzlaşmacılık & 655 & & & & \multirow{3}{*}{$\frac{1}{0}$} \\
\hline & Rekabet &, 532 & & & & \\
\hline & Saygınlık & ,474 & & & & \\
\hline \multicolumn{2}{|c|}{ Toplam Açılanan Varyans: $\% 52,798$} & \multicolumn{5}{|c|}{$\begin{array}{r}\text { Kaizer-Meyer-Olkin Ölçek Geçerliliği: } \\
, 755\end{array}$} \\
\hline \multicolumn{2}{|c|}{ Bartlett Küresellik Testi Ki kare: 2649,192} & \multicolumn{3}{|c|}{ sd: 741} & \multicolumn{2}{|c|}{ p değeri:, 000} \\
\hline
\end{tabular}

İstatistik sonuçları, her iki ölçek için de faktörlerin iç tutarlılığının yüksek olduğunu ve tüm faktörlerin kendi içlerinde anlamlı seviyede farklılaştığını göstermektedir $(\mathrm{p}<0,05)$.

\section{F. Araştırma Hipotezlerinin Test Edilmesi}

Ruhsal Zeka ile Çalışma Algısı Arasındaki İlişkinin Test Edilmesi

$\mathrm{H}_{1}$ : Ruhsal zeka ile çalışma algısı arasında pozitif yönlü anlamlı ilişki bulunmaktadır.

Tablo 3: Ruhsal Zeka İle Çalışma Algısı Arasındaki İlişki İçin Korelasyon Analizi

\begin{tabular}{|c|c|c|c|}
\hline & & SQ & İGA \\
\hline \multirow{3}{*}{ SQ } & Pearson Correlation & 1 & $322^{* * *}$ \\
\hline & Sig. (2-tailed) & & 000 \\
\hline & $\mathrm{N}$ & 219 & 219 \\
\hline \multirow{3}{*}{ İGA } & Pearson Correlation &, $322^{* * *}$ & 1 \\
\hline & Sig. (2-tailed) &, 000 & \\
\hline & $\mathrm{N}$ & 219 & 219 \\
\hline
\end{tabular}

** Correlation is significant at the 0.01 level (2-tailed).

Ruhsal zeka ile çalışma algısı arasında orta seviyede ve 0,01 düzeyde pozitif yönlü anlamlı ilişki bulunmaktadır $\left(\mathrm{r}=0,322, \mathrm{p}<0,05\right.$ ve $\mathrm{H}_{1}$ kabul) (Tablo 3).

Ruhsal zekanın çalışma algısını etkileyip etkilemediğini görebilmek için ANOVA sonuçlarına bakılmıştır (Tablo 4). F değeri anlamlı bulunduğundan bağımsız değişkenin bağımlı değişken üzerinde etkisi vardır $(\mathrm{F}=25,1 ; \mathrm{p}<0,05)$. Dolayısıyla ruhsal zeka ile çalışma algısı için kurulan regresyon modelimiz istatistiksel olarak anlamlı bir modeldir.

Tablo4: Regresyon Analizi İçin ANOVA Tablosu

\begin{tabular}{|c|c|c|c|c|c|c|}
\hline \multicolumn{2}{|c|}{ ANOVA $^{\text {a }}$} \\
\hline \multirow{2}{*}{ Model } & $\begin{array}{c}\text { Sum of } \\
\text { Squares }\end{array}$ & df & $\begin{array}{c}\text { Mean } \\
\text { Square }\end{array}$ & F & Sig. \\
\cline { 2 - 8 } 1 & Regression & 1,593 & 1 & 1,593 & 25,082 &, $000^{\text {b }}$ \\
\cline { 2 - 8 } & Residual & 13,785 & 217 &, 064 & & \\
\cline { 2 - 8 } & Total & 15,379 & 218 & & & \\
\hline
\end{tabular}

a. Dependent Variable: İGA b. Predictors: (Constant), SQ

Tablo 5'e göre; t değeri her düzeyde anlamlı bulunduğundan $(\mathrm{p}<0,05)$ ruhsal zeka değişkeninin katsayısı istatistiksel olarak anlamlıdır. O halde ruhsal 
zekadaki 1 standart sapma miktarı değişim, çalışma algısında \% 32.2 kadar değişime neden olabileceği değerlendirilmiştir.

Tablo 5: Regresyon Katsayıları

Coefficients $^{\mathrm{a}}$

\begin{tabular}{|c|c|c|c|c|c|c|}
\hline \multirow{2}{*}{ Model } & \multicolumn{2}{|c|}{$\begin{array}{c}\text { Unstandardized } \\
\text { Coefficients }\end{array}$} & $\begin{array}{c}\text { Standardized } \\
\text { Coefficients }\end{array}$ & \multirow{2}{*}{$\mathrm{t}$} & \multirow{2}{*}{ Sig. } \\
\cline { 3 - 5 } & B & B & Std. Error & Beta & & \\
\hline \multirow{2}{*}{1} & Constant) & 2,630 &, 112 & & 23,438 &, 000 \\
\cline { 2 - 7 } & sq_ortalama &, 152 &, 030 &, 322 & 5,008 &, 000 \\
\hline
\end{tabular}

a. Dependent Variable: İGA

Özetle modelimizin tahmini sonucu aşağıdaki gibidir:

Çalışma Algısı $=2,630+0,322 *$ (Ruhsal Zeka)

Faktörler Arasındaki İlişkilerin Test Edilmesi

Ruhsal zeka faktörleriyle çalışma algısı faktörleri arasında ilişkiyi test eden 28 alt hipotez $\left(\mathrm{H}_{2 \mathrm{a}} \ldots \mathrm{H}_{2 \mathrm{~g}}, \mathrm{H}_{3 \mathrm{a}} \ldots \mathrm{H}_{3 \mathrm{~g}}, \mathrm{H}_{4 \mathrm{a}} \ldots \mathrm{H}_{4 \mathrm{~g}}, \mathrm{H}_{5 \mathrm{a}} \ldots \mathrm{H}_{5 \mathrm{~g}}\right.$, ) bulunmaktadır.

Tablo 6: Faktörler Arasındaki İlișki İçin Korelasyon Analizi

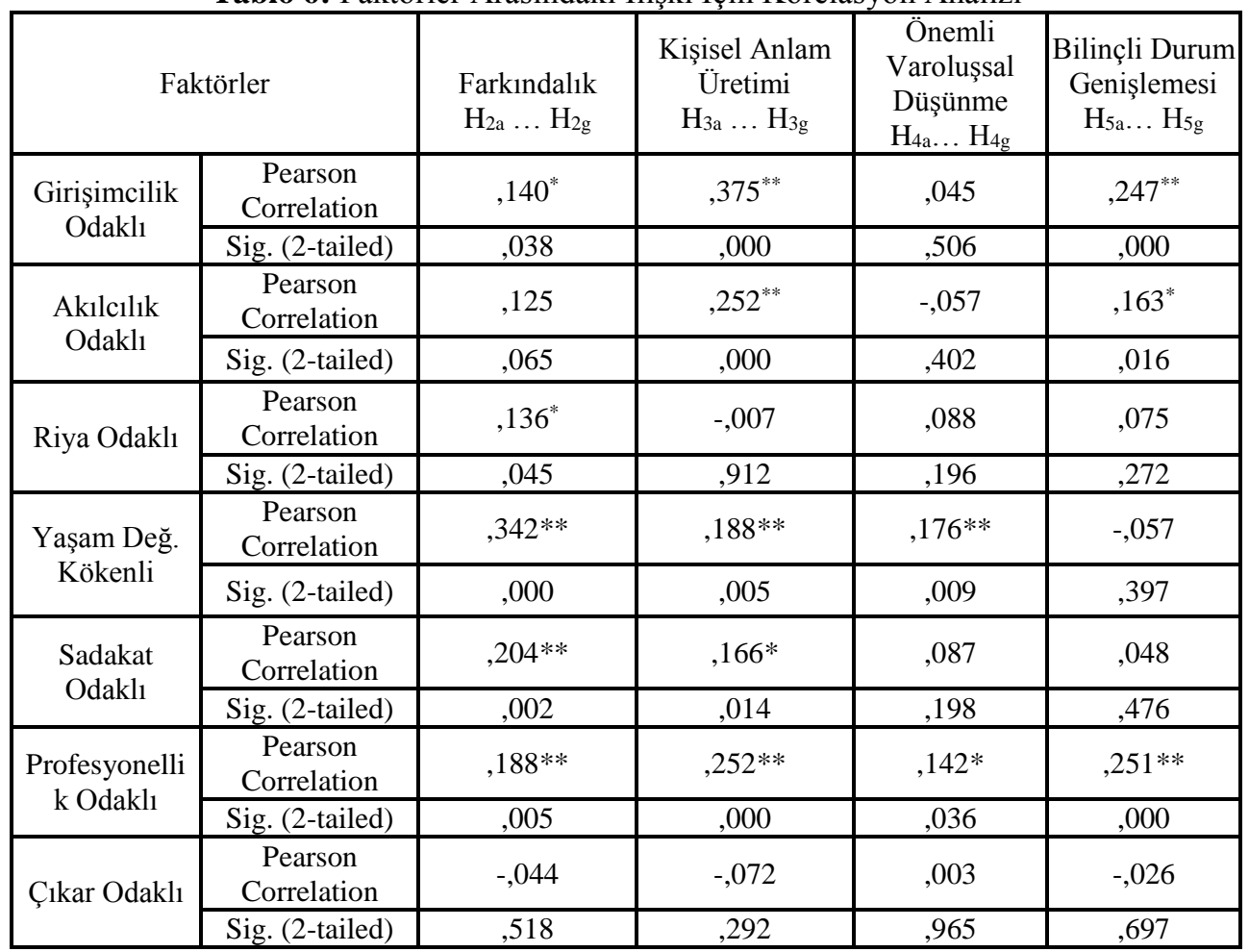

* Correlation is significant at the 0.05 level (2-tailed).

** Correlation is significant at the 0.01 level (2-tailed).

Faktörler arasındaki ilişkiyi gösteren Tablo 6'daki korelasyon analizi incelenerek ilgili 28 hipotez ve sonuçları aşağıdaki gibi verilmiştir. 
$\mathrm{H}_{2}$ : Ruhsal zekanın farkındalık faktörüyle çalışma algısının faktörleri arasında pozitif yönlü anlamlı ilişki bulunmaktadır.

Korelasyon analizine göre $\mathrm{H}_{2}$ hipotezi; çalışma algısının girişimcilik odaklı, riya odaklı, yaşam değerleri kökenli, sadakat odaklı ve profesyonellik odaklı İGA için kabul edilmekte ve ruhsal zekanın farkındalık faktörüyle aralarında pozitif yönlü anlamlı ilişki bulunmaktadır $\left(\mathrm{p}<0,05\right.$; Tablo 6). $\mathrm{H}_{2}$ hipotezi; çalışma algısının akılcılık odaklı ve çıkar odaklı İGA için reddedilmiştir (p > 0,05; Tablo 6).

$\mathrm{H}_{3}$ : Ruhsal zekanın kişisel anlam üretimi faktörüyle çalışma algısının faktörleri arasında pozitif yönlü anlamlı ilişki bulunmaktadır.

$\mathrm{H}_{3}$ hipotezi; çalışma algısının girişimcilik odaklı, akılcılık odaklı, yaşam değerleri kökenli, sadakat odaklı ve profesyonellik odaklı İGA için kabul edilmekte ve ruhsal zekanın kişisel anlam üretimi faktörüyle aralarında pozitif yönlü anlamlı ilişki bulunmaktadır ( $\mathrm{p}<0,05$; Tablo 6). $\mathrm{H}_{3}$ hipotezi; çalışma algısının riya odaklı ve çıkar odaklı İGA için reddedilmiştir ( $p>0,05$; Tablo 6).

$\mathrm{H}_{4}$ : Ruhsal zekanın önemli varoluşsal düşünme faktörüyle çalışma algısının faktörleri arasında pozitif yönlü anlamlı ilişki bulunmaktadır.

$\mathrm{H}_{4}$ hipotezi; çalışma algısının yaşam değerleri kökenli ve profesyonellik odaklı İGA için kabul edilmekte ve ruhsal zekanın önemli varoluşsal düşünme faktörüyle aralarında pozitif yönlü anlamlı ilişki bulunmaktadır ( $p<0,05$;Tablo 6). $\mathrm{H}_{4}$ hipotezi; çalışma algısının girişimcilik odaklı, akılcılık odaklı, riya odaklı, sadakat odaklı ve çıkar odaklı İGA için reddedilmiştir ( $p>0,05$;Tablo 6).

$\mathrm{H}_{5}$ : Ruhsal zekanın bilinçli durum genişlemesi faktörüyle çalışma algısının faktörleri arasında pozitif yönlü anlamlı ilişki bulunmaktadır.

$\mathrm{H}_{5}$ hipotezi; girişimcilik odaklı İGA, akılc1lı odaklı İGA ve profesyonellik odaklı IGA için kabul edilmekte ve ruhsal zekanın bilinçli durum genişlemesi faktörüyle aralarında pozitif yönlü anlamlı ilişki bulunmaktadır ( $\mathrm{p}<0,05$;Tablo 6). $\mathrm{H}_{5}$ hipotezi; riya odakl1, yaşam değerleri kökenli, sadakat odaklı ve çıkar odaklı İGA için reddedilmiştir ( $p>0,05$; Tablo 6).

\section{Araştırma Hipotezlerine İlişkin Bulguların Bazı Demografik Değişkenler ile Test Edilmesi}

Araştırmamızın bu aşamasında yeni bir değişken olarak ruhsal zeka ile demografik değişkenler arasında anlamlı farklılıkların olup olmadığı üzerinde durulacaktır. Katılımcıların çoğunluğu benzer eğitimi aldığı için eğitim düzeyi bir değişken olarak test edilmeyecektir.

$\mathrm{H}_{6}$ : Ruhsal zekanın faktörlerine ait ortalamalarda, cinsiyete göre anlamlı bir farklılık bulunmaktadır.

Analize göre, bu araştırmada ruhsal zekanın bilinçli durum genişlemesi faktör ortalaması kadın katılımcılarda istatistiki açıdan anlamlı olarak daha yüksek bulunmuştur $\left(\mathrm{H}_{6}\right.$ hipotezi, $\left.\mathrm{p}<0,05 ; \mathrm{t}=-2,379\right)$. Kadın ve erkek akademisyenler arasında ruhsal zekanın diğer faktörlerinde istatistiki açıdan anlamlı farklılık bulunmamıştır.

$\mathrm{H}_{7}$ : Ruhsal zekanın faktörlerine ait ortalamalarda, medeni duruma göre anlamlı bir farklılık bulunmaktadır. 
Analize göre, bu araştırmada ruhsal zekanın kişisel anlam üretimi faktör ortalaması evli katılımcılarda istatistiki açıdan anlamlı olarak daha yüksek bulunmuştur $\left(\mathrm{H}_{7}\right.$ hipotezi, $\left.\mathrm{p}<0,05 ; \mathrm{t}=2,097\right)$. Evli ve bekar akademisyenler arasında ruhsal zekanın diğer faktörlerinde istatistiki açıdan anlamlı farklılık bulunmamıştır.

$\mathrm{H}_{8}$ : Ruhsal zekanın faktörlerine ait ortalamalarda, eğitim alanına göre anlamlı bir farklılık bulunmaktadır.

$\mathrm{H}_{8}$ hipotezi, ruhsal zekanın bilinçli durum genişlemesi faktörü için kabul edilmiştir ( $\mathrm{p}<0,05 ; \mathrm{F}=2,764)$. Post-Hoc Tukey testine göre, Fen Bilimlerinde görevli akademisyenler ile Sağlık Bilimlerinde görevli akademisyenler arasında bilinçli durum genişlemesi düzeyinde anlamlı bir farklılık bulunmaktadır.

$\mathrm{H}_{9}$ : Ruhsal zekanın faktörlerine ait ortalamalarda, mesleki tecrübeye göre anlamlı bir farklılık bulunmaktadır.

$\mathrm{H}_{9}$ hipotezi, farkındalık $(\mathrm{p}<0,05 ; \mathrm{F}=2,931)$ ve kişisel anlam üretimi $(\mathrm{p}<0,05 ; \mathrm{F}=3,781)$ faktörleri için kabul edilmiştir. Post Hoc Tukey testine göre; mesleki tecrübesi (7-12 y1l) arası olan akademisyenlerin farkındalık düzeyi ile (16 yıl) ve (19-24 yıl) arası olanlar arasında anlamlı farklılık vardır. Mesleki tecrübesi (7-12 yıl) arası olan akademisyenlerin kişisel anlam üretimi düzeyi ile diğer gruplar arasında anlamlı farklılıklar vardır. (7 -12 yıl) arası olanlar söz konusu faktörlerde gruplar arasında en düşük ortalamayı almışlardır. Ayrıca mesleki tecrübesi ( 7 -12 y1l) arası olanlar ile 25 yıl ve daha çok olan akademisyenlerin ortalaması söz konusu boyutlarda ortalamanın altında değer almıştır.

$\mathrm{H}_{10}$ : Ruhsal zekanın faktörlerine ait ortalamalarda, yetişme dönemindeki aile büyüklügüne göre anlamlı bir farklılık bulunmaktadır.

$\mathrm{H}_{10}$ hipotezi, farkındalık $(\mathrm{p}<0,05 ; \mathrm{F}=4,004)$ ve kişisel anlam üretimi $(\mathrm{p}<0,05 ; \mathrm{F}=4,283)$ faktörleri için kabul edilmiştir. Post Hoc Dunnett t-testine göre; yetişme döneminde aile büyüklügü 2 kişi olan akademisyenlerin, aile büyüklügü daha geniş olanlara göre farkındalık düzeyi daha düşüktür. Yetişme döneminde aile büyüklüğü 2 kişi olan akademisyenlerin sayısı örneklemde az olmakla birlikte, farkındalık düzeyi ortalaması 2,86 iken diğer grupların ortalaması 3,7 ile 4 arasındadır. Post Hoc Tukey testine göre; aile büyüklüğü 4 olanlar ile 6 ve daha geniş olan akademisyenlerin kişisel anlam üretimi düzeyi anlamlı bir şekilde farklılaşmaktadır. Yetişme döneminde aile büyüklüğü 6 ve daha geniş olan akademisyenlerin kişisel anlam üretimi düzeyi ortalaması 4,03 iken aile büyüklüğü 4 kişi olanların kişisel anlam üretimi düzeyi ortalaması $3,63^{`}$ tür.

$\mathrm{H}_{11}$ : Ruhsal zekanın faktörlerine ait ortalamalarda, yaşa göre anlamlı bir farklilık bulunmaktadır.

$\mathrm{H}_{11}$ hipotezi, kişisel anlam üretimi $((\mathrm{p}<0,05 ; \mathrm{t}=3,859)$ ve bilinçli durum genişlemesi $(p<0,05 ; t=2,112)$ faktörleri için kabul edilmiştir. Sonuca göre kişisel anlam üretimi ve bilinçli durum genişlemesi faktör ortalamaları, $X$ kuşağından (doğum tarihi 1960-1979 arasında olan) katılımcılarda, Y kuşağından (doğum 
tarihi 1980-2000 arasında olan) katılımcılara göre istatistiki açıdan anlamlı olarak daha yüksek bulunmuştur.

\section{SONUÇ VE ÖNERILER}

Ruhsal zeka ile çalışma algısı arasında anlamlı düzeyde ilişki olup olmadığını test eden hipotez sonuçlarına göre, yapılan korelasyon analizinde ruhsal zeka ile çalışma algısı ortalamaları arasında anlamlı düzeyde pozitif yönlü ilişki olduğu bulunmuştur. Ruhsal zekanın çalışma algısını ne ölçüde etkilediğini anlayabilmek için yapılan regresyon analizi sonucu, kurulan model istatistiksel olarak anlamlı bulunmuştur. Ruhsal zekadaki 1 standart sapma miktarı değişim, çalışma algısında \% 32.2 kadar değişime neden olabileceği değerlendirilmiştir. $\mathrm{O}$ halde bu araştırma sonuçlarına göre; ruhsal zeka düzeyindeki artış, iş görme anlayışını pozitif yönde etkilemektedir ve ruhsal zeka düzeyinin geliştirilmesi için atılan adımlardan çalışma algısını da olumlu yönde etkileyeceği beklenebilir.

Faktörler arasında ortaya çıkan en yüksek korelasyon; kişisel anlam üretimi faktörüyle girişkenlik, çalışkanlık, iradecilik, ileri görüşlülük, disiplin ve girişimcilik ifadelerinden oluşan girişimcilik odaklı İGA faktörü arasında görülmektedir. O halde, bireyin hayatında amaç ve anlam bulabilmesi, bu amaç doğrultusunda kararlar verebiliyor olması, düşüncelerini, hislerini ve farkındalıklarını kontrol edebilmesi ve yaşamın farkında olması; bir işe çekinmeden girebilmesine, insanlarla kolaylıkla ilişki kurabilmesine, çalışmayı sevmesine, iradeli davranmasına, ileride olabilecekleri önceden düşünebilmesine, sistematik, programlı ve zamanlı olmasına, yeni işlere girerken kaçınmamasına olumlu yönde etkide bulunmaktadır.

Faktörler arasında ortaya çıkan ikinci sırada yüksek korelasyon; farkındalık faktörüyle kanaatkarlık, kadercilik, gelenekçilik, dostluk, milliyetçilik ve din ifadelerinden oluşan yaşam değerleri kökenli İGA faktörü arasında görülmektedir. O halde, hayatın maddesel olmayan yönlerini tanımak, insan hayatında beden, kişilik ve duygulardan daha anlamlı olan niteliklerin olduğunu düşünebilmek, kendini daha iç, derinlemesine, fiziksel olmayan şekilde tanımlayabiliyor olmak, herhangi bir hata yaptığında yine de onun altında bir anlam bulabilmek ve hayatındaki olayların anlamını sık sık düşünmek, kendi ve diğer insanlar arasındaki derin bağın farkında olmak, insanoğlu ve tüm evren arasındaki ilişki hakkında düşünebilmek; bireyi daha kanaatkar yapmakta ve kültürel, milli ve dini değerlere bağl1, dostluk ilişkilerine önem veren bir anlayış kazanmasında etkili olmaktadır diyebiliriz.

Faktörler arasında ortaya çıkan üçüncü sırada yüksek korelasyon ise bilinçli durum genişlemesi faktörüyle profesyonellik odaklı İGA ve girişimcilik odaklı İGA arasında bulunmaktadır. Bu sonuçtan; kişinin bilinç ve farkındalığını artırmak için kendi tekniklerini geliştirebiliyor olmasının, farkındalığı arttığında sorunları ve seçenekleri daha iyi görebiliyor olmasının; iş görürken profesyonellik ve girişimcilik odaklı iş görme anlayışını olumlu yönde destekleyeceğini çıkarabiliriz. 
Ayrıca ruhsal zekanın tüm faktörleriyle profesyonellik odaklı İGA arasında anlamlı düzeyde ilişki bulunmuştur. Bunun tersine, ruhsal zekanın hiçbir faktörüyle çıkar odaklı İGA arasında anlamlı düzeyde ilişki bulunmamıştır.

Ruhsal zeka ile demografik değişkenler arasında anlamlı farklılıkların olup olmadığını test eden analizlere göre, faktörler arasında anlamlı düzeyde bulunan sonuçlar şu şekildedir:

Cinsiyet değişkeni açısından; ruhsal zekanın bilinçli durum genişlemesi ortalaması kadın katılımcılarda anlamlı olarak daha yüksek bulunmuştur.

Medeni durum değişkeni açısından; ruhsal zekanın kişisel anlam üretimi faktör ortalaması evli katılımcılarda anlamlı olarak daha yüksek bulunmuştur.

Eğitim alanı değişkeni açısından; Fen Bilimlerinde görevli akademisyenlerle Sağlık Bilimlerinde görevli akademisyenler arasında ruhsal zekanın bilinçli durum genişlemesi düzeyinde anlamlı bir farklılık bulunmaktadır. $\mathrm{Bu}$ boyuttaki ifadeleri Fen Bilimlerinde görevli akademisyenler kendileri için 'biraz doğruya yakın ifadeler' olarak buluyorken Sağlık Bilimlerinde görevli akademisyenler kendileri için 'çok doğruya yakın ifadeler' olarak bulmuşlardır.

Mesleki tecrübe değişkeni açısından; (7 -12 yıl) arası olanlar ruhsal zekanın farkındalık ve kişisel anlam üretimi faktörlerinde gruplar arasında en düşük ortalamayı almışlardır. Ayrıca mesleki tecrübesi ( 7 -12 yıl) arası olanlarla 25 yıl ve daha çok olanların ortalaması söz konusu boyutlarda ortalamanın altında değer almıştır.

Aile büyüklügü değişkeni açısından; aile büyüklüğü 4 olanlarla 6 ve daha geniş olan akademisyenlerin ruhsal zekanın kişisel anlam üretimi düzeyi anlamlı bir şekilde farklılaşmaktadır. Aile büyüklüğü 6 ve daha geniş olan akademisyenlerin kişisel anlam üretimi düzeyi ortalaması daha yüksektir.

Yaş değişkeni açısından; ruhsal zekanın kişisel anlam üretimi ve bilinçli durum genişlemesi faktör ortalamaları, X kuşağından olan katılımcılarda anlamlı olarak daha yüksek bulunmuştur. Ruhsal zeka ortalamasının X kuşağından olan katılımcılarda anlamlı olarak daha yüksek bulunması ise yazınla uyumludur (Aydintan, 2009).

Çalışmasında SISRI-24 ruhsal zeka ölçeğini kullanan Çat (2014)'ın araştırma bulgularında ruhsal zeka ile cinsiyet ve medeni durum arasında anlamlı bir farklılık bulunmazken, mesleki tecrübesi 0-6 yıl arası olanlarla 25 ve üstü yıl olanlar arasında ruhsal zekaya verilen yanıtlar açısından anlamlı farklılıklar bulunmuştur.

Araştırma akademisyenlerin ruhsal zeka özellikleriyle çalışma algısı arasındaki ilişkilerin niteliği ile sınırlandırılmış ve bu ilişkinin çalışma yaşamındaki diğer kesimlere (sanayi sektörü, sağl1k ve hizmet sektörü gibi) yansımalarının nasıl olduğu sorusuna yanıt arayacak biçimde tasarlanmamıştır. $\mathrm{Bu}$ araştırmadan elde edilen bulgular ve çalışmanın kısıtları, çalışmanın devamı niteliğinde değerlendirilebilecek yeni araştırmalar için aşă̆ıda yer alan bazı önerilerde bulunmaktadır.

Ruhsal zeka özellikleri ile çalışma algısı arasındaki ilişkinin niteliği çalışma yaşamındaki diğer kesimler için de araştırılabilir. Ruhsal zeka özellikleri 
ile çalışma algısı arasındaki ilişkilerin örgüt kültürüne nasıl yansıdığ araştırılabilir. Ruhsal zeka düzeyi ile stres düzeyi, takım çalışması, kişilik, örgütsel bağl1lık, örgütsel vatandaşlık davranışları, iş tatmini, vb. konularda ilişkilerin niteliği ve örgüt kültürü açısından yansımaları araştırılabilir. Ruhsal zeka düzeyinin geliştirilmesi adına neler yapılabileceği araştırılabilir. Örgütlerde ruhsal zeka düzeyinin geliştirilmesine yönelik faaliyetlerin etkisini inceleyen araştırmalar yapılabilir. Özellikle de ruhsal zeka özelliklerinin örgüt yaşamındaki etkilerini görmek açısından söz konusu araştırmalar anlamlı ve faydalı olabilir.

Çağımızın işletmeleri farklı kültürlerden ve kuşaklardan çalışanların bir arada faaliyet gösterdiği mozaik örgüt yapısına sahiptir. İşletmelerin çalışanlarıyla birlikte her açıdan varlıklarını bir bütün olarak sürdürebilmeleri için mozaik metaforundan ebru metaforuna geçiş yapmaları önerilebilir. Mozaikteki parçacıklar yapaydırlar, bütün içinde oldukları gibi kalırlar, kaynaşmazlar ve zamanla aşınarak ayrılırlar. Oysa ebruda renkler iç içe kaynaşmış olağanüstü bir birliktelik ve bütünlük sergiledikleri için isteseniz de ayırmak mümkün değildir.

Attila Durak'ın ifadesiyle “Ebruya uzaktan bakarsanız, renkler karışmış gibi görünür ama yakınına gittiğinizde hiçbir zaman renklerin birbirinin içine girmediğini görürsünüz" (Celal, 2007). Renkler birbirlerine dokunurlar, birbirlerine yer açarlar, ve yoğunluk nedeniyle yüzeyde yer bulamadıkları zaman içe doğru derinleşirler, ama kendi karakterlerini de korurlar. İşte ruhsal zeka bireye ebru metaforundaki gibi bir kişilik kazandırmaktadır. Farklı kültürlerden ve kuşaklardan çalışanların bir arada iş görmesiyle meydana gelen mozaik örgüt yapısında ruhsal zeka yeteneklerinin geliştirilmesiyle çalışanlara ebru karakteri kazandırılabilir ki, işletmelerin istikballeri adına buna ihtiyaçları vardır.

Ruhsal zeka bağlama göre farklı bir anlam ve değer taşıdığından, bir başka ifadeyle insanların içinde yaşadığı kültür ve din gibi toplumun kalıplarına göre ruhsal zekaya yüklenen anlam değişeceğinden bu araştırma farklı bağlamlarda farklı sonuçlar verebilir.

Ancak araştırmanın kuramsal arka planına dayanarak oluşan beklentiye göre; ruhsal zekanın biyolojik yeri olan frontal alanın işlevine dikkatleri yönlendirdiğimizde ruhsal zekanın özünde ayrımcılık, kategorileştirme ve sınıflandırma yerine ebrudaki gibi bütüncül bir anlayış hakimdir. Gerektiğinde prensipler bir başka değişle kırmızı çizgiler esneyebilir. Ruhsal zeka yeteneklerinin geliştirilmesiyle bireylerin, hangi kuşaktan ve kültürden olursa olsun, hem özel hayatında hem iş hayatında birlik ve beraberliği sürdürebilmek, bütünlüğü koruyabilmek için ortak bir amaç ve değerler sisteminde birleşecekleri umulmaktadır.

\section{KAYNAKÇA}

Akgemci, T., ve Bekiş, T. (2013, Ekim). Liderlikte Ruhsal Zeka Üzerine Bir Alan Araştırması. Selçuk Üniversitesi İktisadi ve İdari Bilimler Fakültesi Sosyal ve Ekonomik Araştırmalar Dergi(26), 283-300. http://sead.selcuk.edu.tr/sead/article/download/167/166

Aldemir, C., Arbak, Y., ve Özmen, Ö. (2003). Türkiye’de İşgörme Anlayışı: Tanımı Ve Boyutları. Yönetim Araştırmalarl Dergisi, $\quad 3(1), \quad 5-28$. http://www.yad.baskent.edu.tr/makale.htm\#MAKALELER 
Amram, Y. (2007, August). The Seven Dimensions of Spiritual Intelligence: An Ecumenical, Grounded Theory. Association, Paper Presented at The 115th Annual Conference of The American Psychological. San Francisco, http://www.yosiamram.net/docs/7_Dimensions_of_SI_APA_confr_paper_Yosi_Amram.p df

Aydıntan, B. (2009). Ruhsal Zekânın Dönüştürücü Liderlik Üzerine Etkisini Araştıran Uygulamalı Bir Çalışma. Atatürk Üniversitesi İktisadi ve İdari Bilimler Dergisi, 23(2), 257-274. http://e-dergi.atauni.edu.tr/atauniiibd/article/viewFile/1025003840/1025003668

Baloğlu, N., ve Karadağ, E. (2009). Ruhsal Liderlik Üzerine Teorik Bir Çözümleme. Kuram ve Uygulamada Egitim Yönetimi, $15(58), \quad 165-190$. http://dergipark.ulakbim.gov.tr/kuey/article/viewFile/5000050594/5000047842

Başar, E. (2013). Translational Research: Brain Oscillations In Neuropsychiatric Disease. Dialogues in Clinical Neuroscience, 15(3), 291-300. http://www.dialoguescns.com/publication/brain-oscillations-in-neuropsychiatric-disease/

Bennis, W. (2001). Bir Lider Olabilmek, Çev: Utku Teksöz. İstanbul: Sistem Yayıncılık Bozkurt, V. (2000). Püritanizmden Hedonizme Yeni Çalışma Etiği (1. b.). Bursa: Alesta

Celal, M. (2007, Temmuz 19). Ebru: Kültürel Çeşitlilik Üzerine Yansımalar. Cumhuriyet Kitap Eki. http://www.metiskitap.com/catalog/text/68888

Chaudhary, B., ve Aswal, M. (2013, October 7). Imparting Spiritual Intelligence Curriculum In Our Classrooms. European Academic Research, 1(7), 1508-1515. http://euacademic.org/UploadArticle/112.pdf

Çat, S. (2014). Acil Yardım, Kurtarma Ve Müdahale Çalışanlarının Ruhsal Zeka Ve Tükenmişlik Düzeylerinin Belirlenmesi Üzerine Bir Çalışma: Gümüşhane İli Örneği . (Yayınlanmamış Yüksek Lisans Tezi). Gümüşhane Üniversitesi/Sosyal Bilimler Enstitüsü, Gümüşhane

Covey, S. (2004), The 8th Habit: From Effectiveness to greatness. Free Press

Damasio, A. (1994). Descartes' Error : Emotion, Reason, And The Human Brain. London: Penguin

Damasio, A. R. (2000). The Feeling of What Happens: Body and Evolution in the Making of Consciousness. (1. b.). New York: Harvest

Emmons, R. A. (2000). Is spirituality an intelligence? Motivation, Cognition, and the Psychology of Ultimate Concern. The International Journal for the Psychology of Religion(10), 3-26. Doi:10.1207/S15327582IJPR1001_2

Field, A. (2013). Discovering Statistics Using IBM SPSS Statistics (4. b.). London: Sage.

Forghania, A. K., Dehkordib, A. M., Mobarakic, M. H., ve Toulid, M. N. (2014). Studying the Effects of Employee's Spiritual Intelligence on Work Engagement in Ferdowsi University of Mashhad. Asian Journal of Research in Business Economics, 4(8), 292-304. http://www.indianjournals.com/ijor.aspx $?$ target=ijor:ajrbem\&volume $=4 \&$ issue $=8 \&$ article $=026$

Gardner, H. (2012, Haziran). The Theory of Multiple Intelligences. http://www.pz.harvard.edu/sites/default/files/Theory\%20of\%20MI.pdf

Jensen, E. (1998). Teaching With The Brain Iin Mind (2. b.). Virginia, USA: Association for Supervision and Curriculum Development Alexandria.

Keleş, E., ve Çepni, S. (2006). Beyin Ve Öğrenme Y11 3, Sayı 2, Aralık 2006. Türk Fen Eğitimi Dergisi, 3(2), 66-82. http://egitimarastirmasi.ueuo.com/ogrenme/2006aralik.pdf

Kesken, J., ve Ayyıldız, N. A. (2008). Liderlik Yaklaşımlarında Yeni Perspektifler: Pozitif Ve $\begin{array}{llll}\text { Otantik Liderlik. Ege Akademik Bakls, } & \text { 8(2), } & \text { 729-754. }\end{array}$ https://www.academia.edu/6423052/L\%C4\%B0DERL\%C4\%B0K_YAKLA\%C5\%9EIM LARINDA_YEN\%C4\%B0_PERSPEKT\%C4\%B0FLER

King, D. B. (2008). Rethinking Claims Of Spirttual Intelligence:A Definition, Model, And Measure. (Unpublished Master's Thesis). Trent Unıversity, Canada.

Köse, S., Oral, L., ve Tetik, H. T. (2014). Y Kuşağının Birinci Ve İkinci Yarısında İş Değerlerinin Karşılaştırılması Üzerine Bir Araştırma. HUMANITAS Uluslararası Sosyal Bilimler Dergisi, Uluslararasi Hakemli Dergi(3), 149-165. http://humanitas.nku.edu.tr/article/viewFile/5000107778/5000100511 
Levy, R. B. (2000). My Experience as Participant in The Course of Spirituality for Executive Leadership. Journal of Management Inquiry, 9(2), 129-131. http://jmi.sagepub.com/content/9/2/129.full.pdf+html

Moxley, R. S. (2000). Leadership and Spirit. San Francisco,CA: Jossey-Bass.

Nasel, D. D. (2004). Spiritual Orientation in Relation to Spiritual Intelligence: A Consideration of Traditional Christianity and New Age/Individualistic Spirituality. (Unpublished Doctoral Dissertation). University of South Australia.

Özdemir, S., ve Yiğit Seyfi, Ü. (2015). A Transformation From the Cages of Spirits to the Spiritual Organizations: Different Solutions to Employee Oriented Issues. The 2015 WEI International Academic Conference Proceedings (s. 230-234). Harvard, USA: The West East Institute. http://www.westeastinstitute.com/wp-content/uploads/2015/07/SelimTX.pdf

Pallant, J. (2010). SPSS Survial Manuel (4. b.). New York, USA: McGraw-Hill Open

Singer, W. (1999, February ). Striving for Coherence. Nature, 397, 391-393. http://cognitrn.psych.indiana.edu/busey/erp/Singer_Nature.pdf

Tarhan, N. (2013). Duyguların Psikolojisi (13. b.). İstanbul: Timaş.

Tınar, M. Y. (1996). Çalışma Psikolojisi. İzmir: Necdet Bükey.

Uslu Üstten, A. (2008). Kuantum Biliminin Getirdiği Yenilikler Işığında Ruhsal Zekânın Edebiyat Eğitiminde Kullanılması. (Yayınlanmamış Doktora Tezi). Gazi Üniversitesi Eğitim Bilimleri Enstitüsü, Ankara.

Vaughan, F. (2002). What is Spiritual Intelligence? Journal of Humanistic Psychology, 42(2), 1633. http://www.francesvaughan.com/files/Spiritualintell.pdf

Wolman, R. N. (2001). Thinking With Your Soul: Spiritual Intelligence and Why It Matters. New York: Harmony.

Zohar, D. (2004, September). How The Bush Administration Has Deminished America's Spiritual Capital. Tikkun Magazine(19). http://jstrande.typepad.com/blog/2004/11/leadership_12_k.html

Zohar, D., ve Marshall, I. (2004). Ruhsal Zekamızla Bağlantı Kurmak. (B. Erdemli, ve K. Budak, Çev.) İstanbul: Meta.

\section{SUMMARY}

In today's working conception, it seems to have needed approaches which tackle human as a whole with physical,mental, emotional and spiritual aspects. In this context, spiritual intelligence is a holistic approach and a type of concideration. This reasearch is formed to question the nature of connections between the spiritual intelligence and perception of work.

For the concept of spiritual intelligence, which is the main topic of the research; Firstly, further question was searched for an satisfactory answer. "Is sipirutal intelligence a scientific fact or a legend, which is particularly made to attract the attention of business World?" As a result of extensive literature survey, It has been found that the anatomical and physiological sub-structure meets the necessary criteria in order to qualify psychic abilities as an intelligence. The majority of the basic research revealed that scientists made the nervous base in the brain of the spiritual intelligence evident. Concepts are becoming widespread in international literature such as spirituality, spiritual institutions, workplace spirituality, and spiritual leadership which are related to spiritual intelligence and these concepts may express different aspects of spiritual intelligence.

Spiritual intelligence is a set of skills in which people embody spiritual resources, values and qualities they use it while making meaningful decisions, 
thinking about existing issues, solving daily life problems and at the same time increasing their level of work and wealth. In other words, spiritual intelligence is defined as the practical application of potentially existing spiritual abilities and resources.

At the beginning of the factor, "Is there a meaningful connection between spiritual intelligence and work perception?" This question made people think about the search for meaning, purpose, integrity and sociability in their work. Furthermore, the study perception is not only physical but also related to spiritual reasons; Whatever the source, the use of spiritual solutions predominantly to overcome the distress resulting from perception; The inadequacy or lack of talents in the spiritual and emotional areas impedes the development and growth of the organization; The role and importance of spiritual intelligence in organizational life; Research findings showing that there is a connections between spiritual intelligence and personality; the place of classical management mentality must be supplanted by things which requires heart, mind and soul integrity rather than physical labor; The fact that the transformation of job values is matched with mental intelligence abilities has strengthened the idea that there may be a meaningful relationship between spiritual intelligence and work perception.

Within the scope of this research, it was concluded that there is a meaningful connection between spiritual intelligence and work perception, and the formed model was adopted. The increase in the level of mental intelligence affects the perception of work positively.

Based on the theoretical background of this research we can say that: According to human resources managers, when individuals get a job,it is related to cognitive intelligence levels (IQ) and when they get a promotion, it is related to emotional intelligence levels (EQ) but if individuals demand to be irreplaceable for the institution, it is related to spiritual intelligence levels.

Today's business operations has a mosaic structure in which people from different cultures and generations work together. It is necessary to develop spiritual intelligence skills for the stated institutions to continue their existences together with their employees. Spiritual intelligence makes people produce new things, change the rules when it is necessary, activate the sense of decency, bend the strick rules with compassion and understanding, be able to identify the limits of understanding and compassion, and be able to evaluate events from different perspectives.

Spiritual intelligence, which plays an active role in enriching our inner world is expressed by danah zohar (2004) with 12 attributes: self-awareness, spontaneity, being vision and value led, holism, compassion, celebration of diversity, field independence humility, tendency to ask fundamental "Why?" questions, ability to reframe, positive use of adversity and sense of vocation. These features are learnable skills.

Mankind can improve these skills and take life's success and satisfaction to the higher levels. It is a function of spiritual intelligence to avoid sudden and hot tempered behaviours and to be able to analyze events from various angles, 
both analytically and emotionally, with mind and heart cooperation. Spiritual intelligence makes us show conscious behaviours by adding our thoughts to what we feel.

Differences in perception of work can be made advantageous by developing spiritual intelligence skills. Thus, it is hoped that individuals will unite in a common purpose and values system in order to be able to maintain unity and solidarity in both private and business life, whatever culture and generation they belong to. 